\title{
Key Attributes Influence the Performance of Local Weed Management Programs in the Southwest United States
}

\author{
Mary E. Hershdorfer, ${ }^{1}$ Maria E. Fernandez-Gimenez, ${ }^{2}$ and Larry D. Howery ${ }^{3}$ \\ Authors are ${ }^{1}$ Assistant Manager, NRCS Tucson Plant Materials Center, 3241 N. Romero Road, Tucson, AZ 85705-9223; ${ }^{2}$ Assistant Professor, \\ Department of Forest, Rangeland, and Watershed Stewardship, Colorado State University, Fort Collins, CO 80523-1472; and ${ }^{3}$ Professor and Extension \\ Specialist, School of Natural Resources, University of Arizona, 325 Biosciences East, University of Arizona, Tucson, AZ 85721.
}

\begin{abstract}
In the southwestern United States, local weed management programs are increasingly important in weed prevention and control; however, little is known about the effectiveness of different local approaches to weed management. We surveyed coordinators of 53 local weed management programs in Arizona, Colorado, New Mexico, and Utah to determine how 4 key program attributes (interagency coordination, volunteer participation, regulatory authority and enforcement, and the state in which the program was located) were related with 4 performance measures: weed control, public education and outreach, weed monitoring, and integrated weed management. Based on the responses of 42 program coordinators (79\%) we found that 1 ) weed programs that coordinated their activities with other organizations and those with citizen volunteers conducted more monitoring, but programs that did not coordinate or use volunteers treated more of their infested acreage; 2) programs that used a light-handed regulatory approach conducted more weed control than those with more punitive enforcement regimes or no enforcement authority; and 3) Colorado programs conducted more outreach and education than did programs in the other 3 states. Thus, although volunteer involvement and interagency coordination contributed to the performance of the local weed programs studied, particularly in monitoring, they have not compensated for the lack of locally enforceable weed regulations or adequate funding. Successful weed management in southwestern United States will require adequately funded, locally adapted approaches supported by locally enforceable weed regulations.
\end{abstract}

\section{Resumen}

En el suroeste de Estados Unidos de América, los programas locales de manejo de la maleza cada día son más y más importantes para la prevención y control de estas plantas nocivas, pero poco se sabe respecto a la efectividad de las diferentes estrategias locales de manejo de la maleza. Entrevistamos 53 coordinadores de programas locales de manejo de maleza en Arizona, Colorado, New Mexico y Utah para determinar como cuatro atributos clave del programa (la coordinación entre agencias, la participación voluntaria, la autoridad reguladora y de cumplimiento y el estado en el cual esta localizado el programa) estuvieron relacionados con cuatro medidas de desempeño del programa: control de la maleza, educación pública y concientización, monitoreo de la maleza y manejo integrado de la maleza. En base a las respuestas de 42 coordinadores de programa (79\%) que respondieron encontramos que 1) los programas de manejo de maleza que coordinan sus actividades con otras organizaciones y aquellos con ciudadanos voluntarios conducen mas monitoreo, pero los programas que nos se coordinan o usan voluntarios trataron más superficie infestada; 2) los programas que usaron una regulación legal no tan severa efectuaron más control de maleza que aquellos con regimenes de castigo más rígidos en caso de incumplimiento o sin autoridades para el cumplimiento y 3) Colorado condujo más trabajo de concientización y programas educativos que los otros tres estados. Aunque el involucrar voluntarios y la coordinación entre agencias contribuyó en el desempeño de los programas locales estudiados, particularmente en el monitoreo, ello no ha compensado la falta de leyes locales para el cumplimiento del control de maleza o la falta de financiamiento apropiado. El manejo exitoso de la maleza en suroeste de Estados Unidos de América requerirá de estrategias financiadas adecuadamente, adaptadas localmente y apoyadas en leyes de cumplimiento locales.

Key Words: community-based natural resource management, collective action problem, invasive plants

Research was funded by the US Dept of Agriculture Initiative for Food, Agriculture and Farming Systems.

At the time of research, Hershdorfer was a graduate research assistant, School of Natural Resources, University of Arizona, Tucson, AZ.

Correspondence: Maria E. Fernandez-Gimenez, Dept of Forest, Rangeland, and Watershed Stewardship, Colorado State University, Fort Collins, CO 80523-1472. Email: gimenez@ warnercnr.colostate.edu

Manuscript received 8 June 2005; manuscript accepted 2 March 2007.

\section{INTRODUCTION}

In the United States, community-based approaches to natural resource stewardship have gained increasing popularity over the past decade (Wondolleck and Yaffee 2000; Weber 2003; Fernandez-Gimenez et al. 2004); however, comprehensive evaluations of these approaches are lacking (Conley and Moote 2003). Community-based approaches have been effective in 
addressing various natural resource problems, especially when a resource is used jointly by many individuals and a sustainable management regime requires that a critical mass of resource users cooperate (Ostrom 1990). Such situations pose a collective action problem, because each resource user has little incentive to limit their use and protect the resource if other users do not. In collective action dilemmas, such as the familiar "tragedy of the commons" story, a choice that is rational for an individual results in a suboptimal outcome for the group (Olson 1965; Singleton 1998). Invasive nonnative plants pose a collective action problem because effective prevention and control of weeds requires that a critical mass of landowners in an area participates in weed management in order to control the spread of undesirable plants, but there is little incentive for an individual landowner to control weeds unless all their neighbors also do. Potential remedies for collective action problems include external regulation by government entities, economic incentives, and collective self-regulation and management by local resource users (Olson 1965; Singleton 1998).

In the southwestern United States, invasive nonnative plants such as tamarisk (Tamarix ramosissima Deneb) have been present for a century (Horton 1977); however, local public awareness of the potential threat posed by these plants has lagged behind that of other regions, as has implementation of policies and practices to control the spread of weeds (Cramer 1995). Local weed management organizations conduct much of the on-the-ground weed management and public education in the southwestern United States. These organizations include 4 different types of locally based institutions: county weed programs, weed districts, cooperative weed management areas, and grassroots volunteer weed groups. Although it is useful to classify local weed management organizations into general program types, key organizational attributes likely contribute to the overall success of a weed management program, regardless of program type.

In spite of the prominent role of local weed management programs in addressing weed infestations in the southwestern United States, there has been no attempt to quantify these efforts or to gauge which organizational attributes positively influence the performance of weed management activities. To address this specific knowledge gap and contribute to understanding community-based resource management more broadly, we conducted a 3-year study to assess the influence of 4 key program attributes (interagency coordination, volunteer participation, regulatory authority and enforcement, and the state in which the program was located) on 4 performance measures (weed control, public education and outreach, weed monitoring, and integrated weed management). The primary goal of the study was to examine the current relationship between organizational attributes and performance of local weed management programs, and to inform the future design of new local weed programs formed to address expanding weed infestations in the Southwest.

\section{METHODS}

We used a multiple-case study approach, in which information on each weed management group was gathered through several complementary methods and analyzed quantitatively. Past weaknesses in the analysis of community-based natural resource management institutions include overreliance on single or small-number case studies, and lack of comparison with status quo management institutions (Agrawal 2000; Conley and Moote 2003). We attempted to overcome these weaknesses by conducting a survey of 53 weed management programs. Programs surveyed included conventional local weed management organizations typically characterized by single-agency management and strong local weed regulations, and newer institutions that often involved multiple agencies and organizations as well as citizen volunteers. Newer groups often arose in areas where local weed regulations were weak or lacking.

\section{Study Area}

Our study area comprised Arizona, New Mexico, and the Colorado Plateau regions of Utah and Colorado, defined ecologically by the Sonoran, Chihuahuan, and Colorado Plateau deserts and their associated grasslands, mountains, and riparian areas. We compiled a list of all known local weed management organizations within the study area by contacting state weed coordinators, university cooperative extension weed specialists, county cooperative extension agents, and other knowledgeable individuals. The local weed management organizations we identified fell into the following 4 types: 1 ) county weed programs, 2) cooperative weed management areas, 3) weed districts, and 4) grassroots volunteer weed groups. County programs are found in states with a longer history of institutionalized weed management (in this study, Utah and Colorado), usually have regulatory authority to enforce local weed ordinances, are bounded by county lines, and receive annual funding from the county budget. Weed districts tend to be found in communities historically dependent on crop agriculture, and are created when residents approve a measure to authorize self-taxation for weed control. Cooperative weed management areas coordinate weed management activities and decisions among multiple agencies and organizations within a program area that often follows natural rather than political boundaries. Grassroots volunteer weed organizations are usually initiated by private citizens with a personal interest in weed control and consist of citizen volunteers who donate their time to control weeds, often on public land. At the time of this study, Arizona and New Mexico programs were limited to cooperative weed management areas and grassroots organizations.

Federal agencies such as the US Forest Service, the Bureau of Land Management, and the National Park Service often participate as partners in local weed management organizations, as do some state agencies and nonprofit organizations such as The Nature Conservancy. Because our focus was on locally developed and administered weed management programs, we did not include in our sampling frame programs that were administered primarily by state, federal, or national nonprofit agencies.

\section{Survey Development and Implementation}

We collected preliminary information about local weed management programs and invasive plant issues in each study state through a series of semistructured interviews with 9 key 
informants from December 2001 through February 2002. Beginning with the 4 state weed coordinators, Mary Hershdorfer (first author) used a snowball approach (Bernard 1995) to locate and interview weed experts within the study region. In these interviews, the key informants responded to questions about issues concerning weeds and land use; local weed program structure, activities, and resources; and contact information for additional potential informants.

Based on this information, we developed, pilot-tested, and administered a mail survey questionnaire that included both closed- and open-ended questions. The questionnaire was pilottested on 2 weed experts and 3 weed program coordinators from groups that did not qualify for the study. Following the pilot test, the questionnaire was revised and mailed to the coordinators of the 53 local weed programs identified within the study region. Because the questionnaire was focused on program structure, budget, and activities, and responses did not depend on individual perceptions, we surveyed only the coordinator of each organization, assuming that the coordinator would be the most knowledgeable and accurate source of information on the program's activities and finances.

The initial mailing took place in June 2002, with additional questionnaires sent to newly identified groups through February 2003. Because of the small size of our target population, we surveyed all members of the population rather than a random sample (Dillman 2000; Pagano and Gauvreau 2000). Using a modification of Dillman's (2000) total survey method, the initial questionnaire was followed by a postcard reminder, a follow-up letter and replacement questionnaire, and finally by a phone call to coordinators that had not responded. In total, 42 questionnaires were returned, for a response rate of $79 \%$. Because of the relatively high response rate, no formal nonresponse bias analysis was conducted. There were no differences in program type or state between responding and nonresponding coordinators. Follow-up phone interviews were conducted with all respondents to clarify and elaborate on responses to open-ended questions.

\section{Independent Variables: Program Attributes}

We used program attributes rather than program types (e.g. county program, weed district, weed management area, and grassroots volunteer group) as the basis for analysis, because program types did not consistently share key attributes. For example, although most county weed programs were singleagency efforts, some of them involved coordination among agencies or citizen volunteers. Four key differences in program structure, function, and context were identified as important program attributes based on our initial interviews and literature review: interagency coordination, volunteer participation, regulatory authority and enforcement, and the state in which the program was located. These program attributes were used as independent variables in our analysis.

The coordination variable contrasted programs that coordinated activities and decisions among multiple agencies and organizations with those composed of a single government agency. Theory and research on polycentric institutions suggests that organizations with decentralized authority that coordinate their actions and decisions are more effective at solving collective action problems than monocentric organiza- tions, which retain central authority in a single group (Yaffee and Wondolleck 1995; Ostrom 2000).

Volunteer participation distinguished programs that involved citizen volunteers from those with a volunteer weed advisory board and from programs that did not use any form of volunteer assistance. Citizen volunteers represent an additional labor force (Brown et al. 2001; Brandon et al. 2003) as well as a means of involving a broad base of local stakeholders in weed management (Selin and Chavez 1995; Woodall et al. 2000; Brown et al. 2001). Direct and joint participation of local people in activities such as weed control should increase mutual trust and respect among participants (Leach et al. 2002; Wagner 2006), improving the likelihood of cooperation (Koontz et al. 2004) and enhancing capacity for collective action (Ostrom 1990; Woolcock 1998; Putnam 2000).

Regulatory authority and enforcement compared 3 approaches to regulation and enforcement: 1) programs with no regulatory authority to enforce weed laws (including programs where no local weed laws existed); 2) programs with enforcement authority but which did not enforce the laws, relying instead on tactics that encourage compliance, such as sending warning letters or making personal visits to violators; and 3) programs with enforcement authority and which exercised their authority to its full extent by issuing fines, or in rare instances, placing liens on violators' property. A strong legal framework for weed control is thought to be a necessary, if not sufficient, condition for successful prevention and control of infestations (Perrings et al. 2002; Anderson et al. 2003; Shine et al. 2005; Lodge et al. 2006). Past studies suggested that the institutional framework for regulating weed control was weak in parts of our study region (Cramer 1995). However, some researchers have suggested that regulatory approaches may decrease rather than enhance compliance to reach collective action goals (Tang 1994).

The state in which a program was located was a proxy for the institutional history of weed management in the area. Colorado and Utah had longstanding weed programs and laws (>20 years in existence), whereas Arizona's and New Mexico's weed programs and laws had mostly been developed within the last decade. In addition, many Colorado and Utah counties had local weed ordinances, whereas no Arizona and New Mexico counties had passed local weed laws at the time of this study. The reasons behind these differences in states' histories of weed management are beyond the scope of this paper, but may include factors such as the history of agriculture, and extent of invasions in each state, as well as local culture and receptiveness or resistance to regulatory approaches to management. In this study, we are primarily concerned with the potential implications of these different institutional histories of weed management for the current performance of local weed management programs.

\section{Dependent Variables: Program Performance Measures}

The importance of each program attribute was determined by the strength of its association with 4 program performance measures. The performance measures described below represent critical functions of weed management programs recognized in numerous handbooks from federal, state, and local 
program sources (USDI-BLM 1996; FICMNEW 1998; USDAFS 1998; VanBebber 2001; Anderson et al. 2003).

The amount of weed control conducted was assessed using 2 measures: 1) total average acreage treated per year and 2) proportion of infested acreage treated per year for each program's 5 species of greatest concern. Both measures were used in order to provide a more complete and accurate account of weed control efforts made by each program. For example, one program might treat a large area that still only accounts for a small proportion of the total infestation, while another might treat a large proportion of a small infestation. Neither measure accounted for the density of weeds within the infested acreage, but together they provided an indication of the area over which weeds were treated.

Public education and outreach activities were measured by the frequency with which 10 common education and outreach tools were used during the 5 years prior to the survey (brochures or pamphlets, presentations at fairs or town meetings, school seminars, newspaper inserts or articles, radio or television, internet websites, workshops for agency personnel, public pulling events, demonstration plots, and educating policy makers). The frequency of education activities was measured on a Likert-like scale with possible responses ranging from $1=$ "never done" to $5=$ "done more than once per year." The maximum education score, calculated as the sum of the scores for all activities, was 50 .

Monitoring is considered a key element in a successful weed management program (FICMNEW 1998; Sheley and Petroff 1999; Shine et al. 2005; Lodge et al. 2006). We assessed monitoring performance based on whether groups conducted weed monitoring. In our survey, we asked participants to distinguish monitoring activities from inventory or mapping activities, which are used to identify the initial location and extent of weed infestations in order to plan treatment activities.

Use of integrated weed management (IWM) is believed to lead to more efficient and effective weed control (Masters and Sheley 2001). Integrated weed management is a component of integrated pest management, and includes the use of multiple weed control tactics applied in a compatible manner on a sitespecific basis (Thill et al. 1991; Sheley and Petroff 1999; VanBebber 2001). We attributed the use of IWM to a program if the respondent self-identified as using IWM or reported using a range of different weed control strategies to address specific infestations. The latter criterion was used to capture programs that use the basic principles of IWM but were unfamiliar with the term. Because of the broad definition of IWM applied in our analysis, we may have classified some groups as using IWM when they did not necessarily apply multiple methods in a consciously integrated manner.

\section{Hypotheses}

Based on our initial interviews with key informants, literature review, and professional experience, we developed the following hypotheses about the associations between program attributes and performance measures. First, we expected that programs that coordinated activities and decision-making among multiple agencies or organizations would conduct more weed control, monitoring, IWM, and education and outreach, because they had a greater number of partners to share the work, and potentially a greater number of funding sources. Based on theories of polycentric institutions, we expected that groups that coordinate their activities among multiple agencies and organizations would be more autonomous, more flexible, and better able to serve the diverse interests of local stakeholders (Yaffee and Wondolleck 1995; Ostrom 2000).

Second, we expected that weed programs that enforced weed regulations would be more successful in treating infestations than those that did not, in part because a strong legal infrastructure has been identified as an essential component of a successful weed control program (Perrings et al. 2002; Anderson et al. 2003; Shine et al. 2005; Lodge et al. 2006). A negative association between enforcement and weed control would support the alternative hypothesis that regulatory approaches decrease rather than increase compliance in some collective action situations (Tang 1994). We expected programs that enforce weed regulations to conduct less monitoring and education because the time and resources committed to enforcement would leave less time for other activities. We also expected that strict enforcement would be negatively associated with the use of IWM, because strict regulations in an invasive plants context may discourage innovative solutions. Alternatively, in the field of pollution control, Porter (1991) and Porter and Van der Linde (1995) argued that tougher environmental regulations stimulate technological innovations that ultimately benefit the firms affected by regulations. Finding that enforcement is strongly associated with IWM would support this alternative hypothesis.

Third, we expected that weed programs with citizen volunteers would control more weeds and conduct more education and monitoring because of the labor contributed by volunteers (Brown et al. 2001). In addition, interactions among volunteers are likely to increase cooperation (Leach et al. 2002; Wagner 2006), and citizen involvement helps ensure that local weed programs are salient and socially acceptable to community members (Selin and Chavez 1995; Woodall et al. 2000; Brown et al. 2001).

Finally, we expected a longer institutional history of weed management (indicated by the state in which the program is located) would be associated with greater weed control, because weed control was the primary purpose of early local weed programs.

\section{Analyses}

All variables were assessed for normality and equality of variances, and analyzed using SPSS Version 10.0 (SPSS 1999). Due to nonnormality and unequal variances in many of the variables, nonparametric Kruskal-Wallis and Wilcoxon Rank Sum tests were used to compare the response of continuous, numerical variables among categorical factors. Fisher's Exact test was used to test for association among categorical variables. Fisher's Exact test is preferable in cases with low expected cell counts (due to the small population size) because it relies on actual counts rather than approximations (Agresti and Finlay 1997). Means and medians were considered different at $P<0.10$. Open-ended questions in the survey were coded and categorized and used to help interpret and explain patterns in the analysis (Bryman and Burgess 1994). 
Table 1. Descriptive characteristics of 4 types of local weed programs in the southwestern United States. Data presented are the number of groups in each category, unless otherwise stated.

\begin{tabular}{|c|c|c|c|c|c|}
\hline \multirow[b]{2}{*}{ Program characteristics } & \multicolumn{4}{|c|}{ Type of weed program } & \multirow[b]{2}{*}{$\begin{array}{c}\text { Total } \\
(n=42)\end{array}$} \\
\hline & $\begin{array}{l}\text { County program } \\
\quad(n=11)\end{array}$ & $\begin{array}{l}\text { Weed district } \\
\quad(n=2)\end{array}$ & $\begin{array}{l}\text { Weed management area } \\
\qquad(n=24)\end{array}$ & $\begin{array}{l}\text { Grassroots volunteer } \\
\text { group }(n=5)\end{array}$ & \\
\hline \multicolumn{6}{|l|}{ State } \\
\hline Arizona & 0 & 0 & 9 & 1 & 10 \\
\hline Colorado & 4 & 2 & 3 & 0 & 9 \\
\hline New Mexico & 0 & 0 & 10 & 3 & 13 \\
\hline Utah & 7 & 0 & 2 & 1 & 10 \\
\hline \multicolumn{6}{|l|}{ Interagency coordination } \\
\hline Single agency & 8 & 1 & 2 & 0 & 11 \\
\hline Multiple agencies & 3 & 1 & 22 & 5 & 31 \\
\hline \multicolumn{6}{|l|}{ Enforcement } \\
\hline Active enforcement & 6 & 2 & 4 & 0 & 12 \\
\hline Authority to enforce & 3 & 0 & 1 & 1 & 5 \\
\hline No enforcement & 2 & 0 & 18 & 4 & 24 \\
\hline \multicolumn{6}{|l|}{ Volunteers } \\
\hline Citizen volunteers & 1 & 1 & 20 & 5 & 27 \\
\hline Volunteer weed board & 2 & 1 & 1 & 0 & 4 \\
\hline No volunteers & 7 & 0 & 3 & 0 & 10 \\
\hline \multicolumn{6}{|l|}{ Funding source } \\
\hline County budget & 11 & 1 & 7 & 0 & 19 \\
\hline Mil levy & 1 & 2 & 2 & 1 & 6 \\
\hline Agency funds & 5 & 0 & 18 & 4 & 27 \\
\hline Grants & 4 & 1 & 14 & 2 & 21 \\
\hline Provide cost-sharing & 9 & 1 & 12 & 2 & 24 \\
\hline Average program area ( 1000 s of acres) & 2500 & 1427 & 2808 & 496 & 2376 \\
\hline \multicolumn{6}{|c|}{ Average program area by land ownership (\%) } \\
\hline US Forest Service & 15 & 22 & 24 & 18 & 21 \\
\hline Bureau of Land Management & 37 & 47 & 26 & 20 & 29 \\
\hline State & 8 & 1 & 11 & 5 & 9 \\
\hline County & 2 & 3 & 1 & 8 & 3 \\
\hline Private & 28 & 22 & 25 & 33 & 26 \\
\hline Tribal & 6 & 0 & 3 & 3 & 4 \\
\hline Other (e.g. National Park Service) & 5 & 0 & 9 & 18 & 8 \\
\hline
\end{tabular}

\section{RESULTS}

\section{Respondent Characteristics}

Forty-two weed program coordinators responded to our survey, representing 11 county weed programs, 2 weed districts, 24 weed management areas, and 5 grassroots volunteer weed groups. The distribution of these program types by state and their descriptive characteristics are presented in Table 1. Respondents included 10 groups each from Arizona and Utah, 13 from New Mexico, and 9 from Colorado. Thirty-one (74\%) of the responding coordinators were from multiple-agency organizations, $27(64 \%)$ involved citizen volunteers, and 4 $(10 \%)$ involved volunteers through a weed advisory board. More than half of the responding programs $(24 ; 57 \%)$ reported that they had no authority to enforce local weed regulations. Of the remaining 17 groups with enforcement authority, 12 employed punitive measures such as fines and 5 did not.

The oldest program, located in Utah, was established in 1948. The oldest group surveyed in Colorado dated from 1968, whereas the oldest programs surveyed in Arizona and New Mexico were established in 1994 and 1996, respectively.

Respondents' average annual program budget for 2001 ranged from $\$ 0$ to $\$ 200000$. Colorado programs had the largest mean annual budgets (\$83 $777 \pm 61283$ SD), followed by Utah (\$52 $745 \pm 55983)$, New Mexico (\$19615 32 859) and Arizona (\$8 $285 \pm 18$ 499). Annual expenditures on weed control in 2001 followed the same pattern: $\$ 44478 \pm 41542$ in Colorado, \$42 $085 \pm 48289$ in Utah, $\$ 14909 \pm 29452$ in New Mexico, and \$3 $335 \pm 8762$ in Arizona. Colorado programs also spent twice as much on education and outreach $(\$ 8034 \pm 6170)$ as Utah $(\$ 3495$ \pm 7 043), and New Mexico (\$495 \pm 994) and Arizona $(\$ 75 \pm 212)$ trailed behind.

\section{Performance Measures}

The amount of weed control accomplished was dependent upon program attribute (Table 2). Contrary to our hypothesis, single-agency programs treated a significantly greater pro- 
Table 2. Associations between 4 program attributes and the weed control efforts conducted by local weed management programs in the southwestern United States. Data presented are medians and interquartile range (IQR). Differences were assessed using Wilcoxon Rank Sum or Kruskal-Wallis tests and considered significant at $P<0.10$.

\begin{tabular}{|c|c|c|c|c|c|c|c|}
\hline \multirow[b]{2}{*}{ Program attribute } & \multicolumn{4}{|c|}{ Proportion of infested area treated per year (\%) } & \multicolumn{3}{|c|}{ Infested area treated per year (acres) } \\
\hline & $N$ & Median & IQR & $P$ value & Median & IQR & $P$ value \\
\hline \multicolumn{8}{|l|}{ Interagency coordination } \\
\hline Single agency & 9 & 21 & 64 & & 1740 & 4045 & \\
\hline Multiple agencies & $22-29$ & 6 & 14 & 0.026 & 304 & 938 & 0.053 \\
\hline \multicolumn{8}{|l|}{ Enforcement } \\
\hline Active enforcement & 10 & 10 & 28 & 0.078 & 491 & 6668 & 0.116 \\
\hline Authority to enforce & 5 & 39 & 95 & & 2500 & 6788 & \\
\hline No authority & $15-22$ & 4 & 13 & & 280 & 1026 & \\
\hline \multicolumn{8}{|l|}{ Volunteers } \\
\hline Citizen volunteers & $19-25$ & 6 & 9 & 0.048 & 515 & 1609 & 0.978 \\
\hline Volunteer weed board & 4 & 44 & 85 & & 452 & 11065 & \\
\hline No volunteers & $7-8$ & 21 & 54 & & 397 & 4700 & \\
\hline \multicolumn{8}{|l|}{ State } \\
\hline Arizona & $7-9$ & 7 & 7 & 0.063 & 255 & 1054 & 0.12 \\
\hline Colorado & 9 & 10 & 74 & & 1650 & 4326 & \\
\hline New Mexico & $7-12$ & 3 & 13 & & 227 & 801 & \\
\hline Utah & 8 & 19 & 85 & & 670 & 8035 & \\
\hline
\end{tabular}

portion and area of their infestations per year than did multiple-agency programs. Programs that had regulatory authority, but that did not actively enforce their regulations, treated a greater proportion of their infestations than the programs lacking regulatory authority or those with active enforcement regimes. Programs without volunteers and those whose volunteers consisted of a weed board treated a signifi-

Table 3. Associations between 4 program attributes and the education and outreach activities conducted by local weed management programs in the southwestern United States. The education and outreach score is the sum of the frequency with which 10 different outreach and education activities were conducted by each group. Data presented are medians and interquartile range (IQR). Differences were considered significant using Wilcoxon Rank Sum or Kruskal-Wallis tests at $P<0.10$.

\begin{tabular}{|c|c|c|c|c|}
\hline \multirow[b]{2}{*}{ Program attribute } & \multirow[b]{2}{*}{$N$} & \multicolumn{2}{|c|}{$\begin{array}{l}\text { Education and } \\
\text { outreach score }\end{array}$} & \multirow[b]{2}{*}{$P$ value } \\
\hline & & Median & IQR & \\
\hline \multicolumn{5}{|l|}{ Interagency coordination } \\
\hline Single agency & 11 & 14.0 & 12.0 & 0.269 \\
\hline Multiple agencies & 31 & 12.0 & 15.0 & \\
\hline \multicolumn{5}{|l|}{ Enforcement } \\
\hline Active enforcement & 12 & 14.0 & 8.0 & 0.843 \\
\hline Authority to enforce & 5 & 20.0 & 22.0 & \\
\hline No authority & 24 & 12.5 & 16.0 & \\
\hline \multicolumn{5}{|l|}{ Volunteers } \\
\hline Citizen volunteers & 27 & 14.0 & 16.0 & 0.897 \\
\hline Volunteer weed board & 4 & 15.5 & 13.0 & \\
\hline No volunteers & 10 & 13.0 & 9.0 & \\
\hline \multicolumn{5}{|l|}{ State } \\
\hline Arizona & 10 & 10.0 & 19.0 & 0.026 \\
\hline Colorado & 9 & 20.0 & 10.0 & \\
\hline New Mexico & 13 & 13.0 & 18.0 & \\
\hline Utah & 10 & 12.0 & 17.0 & \\
\hline
\end{tabular}

cantly greater proportion of their infestations than did programs with private citizen volunteers. Utah programs treated a greater proportion of their infestations than programs in other states.

Contrary to our expectations, state was the only program characteristic that influenced education and outreach activities (Table 3). State, a proxy for the history of weed management in the area, was associated with many of the specific education activities as well as the overall activity score. Colorado programs had the highest overall education activity score of the 4 states, with Arizona, New Mexico, and Utah showing similar educational scores.

Although all programs reported that treated areas were monitored, some programs monitored with greater consistency than others. Coordination, citizen volunteers, and state influenced the consistency of monitoring (Table 4). As hypothesized, multiple-agency programs conducted monitoring more consistently than single-agency programs. Also in line with our hypotheses, programs with citizen volunteers conducted monitoring more consistently than programs without volunteers or those with a volunteer advisory board only. New Mexico programs monitored more than the other 3 states' programs, whereas Colorado programs monitored least consistently (Table 4).

None of the program attributes influenced the tendency to apply IWM techniques.

\section{DISCUSSION}

Both theory and empirical evidence suggest that locally devised, decentralized approaches to natural resource management problems may be as effective as top-down regulatory approaches (Ostrom 1990; Tang 1994; Agrawal and Gibson 2001). This is especially true in situations where coordinated 
Table 4. Associations between 4 program attributes and the monitoring consistency of local weed management programs in the southwestern United States. Statistically significant differences were determined using Fisher's Exact test at $P<0.10$.

\begin{tabular}{lrcc}
\hline & \multicolumn{3}{c}{ Do you monitor? } \\
\cline { 2 - 4 } Program attribute & \multicolumn{1}{c}{ Yes } & Sometimes & $P$ value \\
\hline Inter-agency Coordination & ------- Number $(\%)$-------- & \\
Single agency & $4(36.4)$ & $7(63.6)$ & 0.042 \\
Multiple agencies & $21(72.4)$ & $8(27.6)$ & \\
Enforcement & & & \\
No authority & $14(63.6)$ & $8(36.4)$ & 0.659 \\
Authority to enforce & $2(40.0)$ & $3(60.0)$ & \\
Active enforcement & $8(66.7)$ & $4(33.3)$ & \\
Volunteers & & & \\
Citizen volunteers & $19(76.0)$ & $6(24.0)$ & 0.040 \\
Volunteer weed board & $1(25.0)$ & $3(75.0)$ & \\
$\quad$ No volunteers & $4(40.0)$ & $6(60.0)$ & \\
State & & & \\
Arizona & $6(66.7)$ & $3(33.3)$ & 0.037 \\
Colorado & $2(22.2)$ & $7(77.8)$ & \\
New Mexico & $10(83.3)$ & $2(16.7)$ & \\
Utah & $7(70.0)$ & $3(30.0)$ & \\
\hline
\end{tabular}

actions are required of many individuals to overcome a collective action dilemma, but the local political or social climate makes government regulation from outside the region unpopular or untenable (Ostrom 2000). Invasive plants pose a collective action problem because individual incentives to shirk responsibility for weed control are great, as are the collective costs of inaction (Perrings et al. 2002). Local weed management programs take a variety of forms, but all strive to overcome the collective action dilemma in weed control by encouraging widespread local participation in weed prevention and control. This study was the first of its kind to determine which key attributes of local weed management programs in the southwestern United States are most critical in positively influencing weed control, education and outreach, monitoring, and integrated weed management.

\section{Weed Control}

Weed control was the major purpose of early invasive plant management programs in the United States, and continues to be a crucial activity for most programs. Our results show that single-agency programs surpassed multiple-agency programs in their treatment of infestations, contrary to our hypothesis (Table 2). We expected that multiple-agency programs would have access to a greater number of funding sources for weed control, and that greater coordination would facilitate control by promoting cross-jurisdictional cooperation and labor-sharing. Several factors may explain why single-agency programs outperformed multiple-agency groups in weed control. First, more funding sources do not necessarily translate into more total dollars for weed control. Although multiple-agency programs were twice as likely to receive funding from both grants and their associated agencies (Hershdorfer 2004), singleagency annual program budgets (median $=\$ 55$ 000), derived primarily from county budgets or mil levies, were well established and much larger than multiple-agency program budgets (median $=\$ 5000)$, and were primarily dedicated to weed control. Second, most single-agency programs were initiated prior to 1980 and therefore have had a longer time to establish weed control efforts across their program areas, compared with multiple-agency programs, most of which began in the mid-to-late 1990s (Hershdorfer 2004).

We expected weed programs with active regulatory programs to conduct more weed control. However, we found that groups that had regulatory authority but which refrained from punitive enforcement measures such as fines treated higher portions and total acreages of infestations (Table 2). These findings suggest that the presence of locally enforceable weed regulations may be more important for weed control than actual enforcement of these regulations. Although this finding has potentially important implications for future program design, it merits further evaluation with a greater number of programs over a larger geographical area; only 5 programs in this population had regulatory authority but used a light-handed approach.

In interviews, several program coordinators elaborated on their reasons for avoiding strict enforcement measures. A weed manager in southern Utah explained his philosophy of avoiding taking an antagonistic role with landowners:

We try to control state-listed weeds, but we don't prosecute offenders. We could enforce them, but we've chosen not to. The law in the state of Utah says we can send letters, and if they refuse, we can come in and charge. Some counties think it's effective to be hard-handed and nasty. We choose to use other methods - we subsidize [with a cost-share program].

The use of economic incentives such as cost-sharing and nonthreatening measures including reminder letters has helped these programs avoid enforcement actions such as placing liens or repossessing properties. Programs such as these may have conducted more weed control because they spent less time and resources on enforcement. A program coordinator from Colorado explained it this way:

Enforcement is rare because, honestly, of staffing levels. There just isn't enough time for that - treat the roads, do the public education, and work with all the other agencies. I have prioritized the last 3 items over enforcement.

Even reminder "pre-enforcement" letters may be viewed as too antagonistic in some social environments, according to one New Mexico program coordinator:

We've done education programs to all that would listen. We've gotten the message out! A letter to people telling them they have weeds on their properties would only create animosity.

Higher levels of weed control in areas with less active enforcement may also reflect less need for enforcement because of greater public awareness of why and how to treat weeds. Awareness may increase after legislation is passed, but it may also precede lawmaking; public policy theory suggests that regulations are more likely to be implemented where there is public support for them (Ingram and Schneider 1991).

Contrary to our expectation, programs with a volunteer weed board and programs without volunteers treated a greater 
percent of their infestations each year than programs with citizen volunteers (Table 2). Several program managers related that volunteers were less suited to herbicide application, compared to activities such as education and monitoring. A program manager in southern Utah commented that because of the physiology of the plant, and the requirement of herbicide for its control, volunteers were not of much use to their program. When volunteers directly participate in weed control activities, they most often engage in manual weed pulling, which is time and labor intensive and can only be used over a relatively small area.

\section{Public Education and Outreach}

Increasing public awareness of the detrimental effects of invasive plants is another crucial function of weed programs, particularly in areas where public awareness is low, such as the southwestern United States (Cramer 1995). Studies have shown that public awareness about societal issues can be increased through education and outreach techniques (Hines et al.1987; Manzo and Weinstein 1987; Donnelly and Vaske 1995; Ackerman 1997). Heightened public awareness also ultimately influences policy, because widespread concern from the general public increases pressure on land mangers and policy makers to shift priorities and take action (Schneider and Ingram 1990).

Public outreach, as one Utah weed program coordinator put it, "has little cost-only time." Even though education and outreach are less costly than weed control, and several programs in Arizona and New Mexico focused exclusively on public education, Colorado programs conducted public outreach more often than those in any other state. This finding contradicts our prediction that Arizona and New Mexico programs, which are younger and have smaller program budgets, would perform more public outreach. Comparing their program to others in the state, one Arizona coordinator reported, "We started with no money, but there's no time to write grants. Here the emphasis is an educational role. Other programs in the state started with funding-their emphasis is on eradication." Arizona programs had the lowest annual budgets of any state, which helps explain their limited activities overall, including outreach and education.

Local weed programs have existed for many years in Colorado and their annual budgets were the highest, on average, of any of the 4 study states. Two recent Governor's Executive Orders in Colorado (D 006 99, Development and Implementation of Noxious Weed Management Programs, and D 002 03, Directing State Agencies to Coordinate Efforts for the Eradication of Tamarisk on State Lands) directed the establishment of cooperative weed management areas and prioritization of invasive plant education for the public and natural resource agency employees (E. Lane, personal communication, December 2001). These statewide policy changes are evidence of Colorado's commitment to improving weed control strategies, and may help explain the high frequency of and investment in educational activities by local weed programs in that state.

\section{Monitoring}

Consistent with our expectations, multiple-agency programs, programs with citizen volunteers, and programs in states with a short history of local weed management monitored more consistently than their counterparts to assess changes in weed infestations after treatment activities (Table 4). Groups with citizen volunteers may have monitored more because monitoring was a more suitable activity for volunteers than some weed control activities, such as herbicide application.

\section{CONCLUSIONS}

Our study reveals benefits and drawbacks to several key attributes of local weed programs in the southwestern United States. We conclude with 3 primary findings. First, weed programs that coordinated their activities with other organizations and programs with citizen volunteers conducted more monitoring, but treated less of their infested acreage every year. Second, the presence of locally enforceable weed regulations was important, but programs that used a light-handed approach to enforcement conducted more weed control than those that used more punitive measures. Finally, weed programs in Colorado invested more in outreach and education to promote weed control than did programs in other states; weed programs in Colorado also conducted more outreach activities. In summary, interagency coordination, volunteer participation, enforceable regulations, and adequate funding each contributed to program effectiveness, but trade-offs between some of these factors were apparent.

Our study suggests that although community involvement and interagency coordination can contribute to the performance of local weed programs, particularly in monitoring infestations, these program characteristics have not yet compensated for a lack of locally enforceable weed regulations or adequate funding for weed control and education in the southwestern United States. Inadequate funding in relation to increasing demands was perceived as a problem by many of the weed program coordinators we interviewed, even those from Colorado, which had the highest average funding levels.

Finally, we used state as a proxy for the institutional history of weed management in our study areas, and also found state to be strongly related to funding levels of local weed management programs. Programs differed by state in all performance measures except use of IWM. In this discussion, we have attributed many of these performance differences to the contrasting institutional histories and funding levels of the 4 states. However, institutional history and funding do not completely explain the observed differences among states. For example, Colorado programs conducted more educational activities than did programs in any other state, even though Utah programs have a similarly long history, and receive the second highest level of funding, on average, following Colorado. Thus, the distinct and complex histories of local cultures, land use, and weed invasions in each of these states may have had a greater influence on our findings than we have been able to discern from our surveys and interviews.

This study fills a gap in understanding factors that influence the performance of local weed management institutions in the southwestern United States, but much work remains to be done. Important areas for future research on the human dimensions of local weed management include the following: 1) assessing the effectiveness of weed program educational 
efforts in influencing citizen knowledge, attitudes, and behavior (see Hodur et al. 2006, for example); 2) evaluating the relative effectiveness of various positive (e.g., cost-sharing) and negative (e.g., fines) incentives in obtaining individual compliance with weed regulations; and 3) identifying the institutional arrangements that promote collective action for weed management on rangelands (see Amatya 2005, for example). Further, although our study examined existing local weed programs in the southwestern United States in 2003, conducting similar studies of weed management organizations across a broader region would help determine whether our findings apply to the larger population of local weed programs on a regional or national scale.

\section{MANAGEMENT AND POLICY IMPLICATIONS}

Our findings suggest several actions that could be taken at the local, state, and federal levels to improve the success of local weed management programs in the southwestern United States. Individual weed management programs, or local groups of individuals or agencies considering the formation of a weed management organization, should consider the potential benefits of involving citizen volunteers and coordinating among multiple agencies. Coordination among multiple agencies and involvement of citizen volunteers facilitate weed monitoring, which in turn helps to promote long-term success in weed management. Our findings support the recommendations of a recent report from the Ecological Society of America (Lodge et al. 2006) on the use of volunteers and enhanced interagency coordination to identify and monitor invasions. Although the number of groups with volunteer weed advisory boards was small in our study, our results suggest that establishing weed boards to help prioritize and guide local weed control activities may also promote effective control.

In addition, local and state governments should ensure that the legal framework exists to support weed prevention and control by establishing locally enforceable local and state weed regulations and the capacity to enforce them. Only 5 groups in this study had enforcement authority but chose not to use it, but the superior performance of these groups in weed control suggests that local enforcement agents should consider emphasizing public education and economic incentives such as costsharing over penalties for failure to control weeds.

Finally, policy makers at all levels must commit significant financial resources to support not only weed treatment, but also public education and monitoring, for effective long-term weed prevention and control.

\section{LITERATURE CITED}

Ackerman, F. 1997. Why do we recycle? Markets, values and public policy. Washington, DC: Island Press. $210 \mathrm{p}$.

Agrawal, A. 2000. Common resources and institutional sustainability. In: E. Ostrom, T. Dietz, N. Dolsak, P. Stern, S. Stonich, and E. Weber [EDS.]. The drama of the commons. Washington, DC: National Academy Press. p 41-85.

Agrawal, A., and C. C. Gibson. 2001. The role of community in natural resource conservation. In: A. Agrawal and C. C. Gibson [EDs.]. Communities and the environment: Ethnicity, gender, and the state in community-based conservation. Piscataway, NJ: Rutgers University Press. p 1-31.
Agresti, A., and B. Finlay. 1997. Statistical methods for the social sciences. 3rd ed. Upper Saddle River, NJ: Prentice Hall. 706 p.

AmatYa, P. 2005. Problems of provision, externality and efficiency, and the case of coalition-based invasive weed management in the Southwest [dissertation]. Logan, UT: Utah State University. 112 p.

Anderson, G. L., E. S. Delfosse, N. R. Spencer, C. W. Prosser, and R. D. Richard. 2003. Lessons in developing successful invasive weed control programs. Journal of Range Management 56:2-12.

Bernard, R. 1995. Research methods in cultural anthropology: Qualitative and quantitative approaches. New York, NY: Altamira Press. 753 p.

Brandon, A., G. Spyreas, B. Molano-Flores, C. Carroll, and J. Ellis. 2003. Can volunteers provide reliable data for forest vegetation surveys? Natural Areas Journal 23:254-261.

Brown, W. T., M. E. Krasny, and N. Schoch. 2001. Volunteer monitoring of nonindigenous invasive plant species in the Adirondack Park, New York. Natural Areas Journal 21:189-196.

Bryman, A., and R. G. Burgess [eds.]. 1994. Analyzing qualitative data. London, United Kingdom: Routledge. 232 .

Conley, A., and A. Moote. 2003. Evaluating collaborative natural resource management. Society and Natural Resources 16:371-386.

Cramer, G. C. 1995. Analysis and implementation of noxious weed policy on Bureau of Land Management and Forest Service lands in Arizona [dissertation]. Tucson, AZ: University of Arizona. $86 \mathrm{p}$.

Dillman, D. A. 2000. Mail and telephone surveys. 2nd ed. Chichester, United Kingdom: Wiley. $494 \mathrm{p}$.

Donnelly, M. P., and J. J. Vaske. 1996. Predicted attitudes towards a proposed moose hunt. Society and Natural Resources 8:301-319.

[FICMNEW] Federal Interagency Committee for Management of Noxious and Exotic WeEDS. 1998. Pulling together: National strategy for invasive plant management. 2nd ed. Washington, DC: US Government Printing Office. 22 p.

Fernandez-Gimenez, M. E., S. Lefebre, A. Conley, and A. Tendick. 2004. Collaborative stewardship of Arizona's rangelands: making a difference in resource management. Rangelands 26:24-30.

Hershdorfer, M. E. 2004. Evaluating local invasive plant management programs in the southwest [thesis]. Tucson, AZ: University of Arizona. $179 \mathrm{p}$.

Hines, J. M., H. R. Hungerford, and A. N. Tomera. 1987. Analysis and synthesis of research on responsible behaviour: a meta-analysis. Journal of Environmental Education 18:1-8.

Hodur, N. M., F. L. Leistritz, And D. A. Bangsund. 2006. Evaluation of TEAM leafy spurge project. Rangeland Ecology and Management 59(5):483-493.

HoRTON, J. S. 1977. The development and perpetuation of the permanent tamarisk type in the phreatophyte zone of the southwest. In: R. Roy Johnson and Dale A. Jones [TECH. COORDS.]. Importance, preservation and management of riparian habitat: A symposium. Washington, DC: US Forest Service. Report GTR-RM 43. p 124-127.

Ingram, H., and A. Schnelder. 1991. The choice of target populations. Administration and Society 23:333-356.

Koontz, T., T. Steelman, J. Carmin, K. Smith Korfmacher, C. Moseley, and C. Thomas. 2004. Collaborative environmental management: What roles for government? Washington, DC: Resources for the Future. 210 p.

Leach, W. D., N. W. Pelkey, and P. A. Sabatier. 2002. Stakeholder partnerships as collaborative policymaking: evaluative criteria applied to watershed management in California and Washington. Journal of Policy Analysis and Management 21(4):645-670.

Lodge, D. M., S. Williams, H. J. Maclsaac, K. R. Yahes, B. Leung, S. Reichard, R. N. Mack, P. B. Moyle, M. Smith, D. A. Andow, J. T. Carlton, and A. McMichael. 2006. Biological invasions: recommendations for US policy and management. Ecological Applications 16(6):2035-2054.

Manzo, L. C., and N. D. Weinstein. 1987. Behavior commitment to environmental protection: a study of active and nonactive members of the Sierra Club. Environment and Behavior 19:673-694.

Masters, R. A., and R. L. Sheley. 2001. Principles and practices for managing rangeland invasive plants. Journal of Range Management 54:502-517.

OLson, M. 1965. The logic of collective action. Cambridge, MA: Harvard University Press. $176 \mathrm{p}$. 
Ostrom, E. 1990. Governing the commons: The evolution of institutions for collective action. New York, NY: Cambridge University Press. 280 p.

Ostrom, E. 2000. The danger of self-evident truths. PS Online: 33-44.

Pagano, M., and K. Gauvreau. 2000. Principles of biostatisics. 2nd ed. Pacific Grove, CA: Duxbury. 525 p.

Perrings, C. M., M. Williamson, E. B. Barbier, D. Delfino, S. Dalmazzone, J. Shogren, P. Simmons, and A. Watkinson. 2002. Biological invasion risks and the public good: an economic perspective. Conservation Ecology 6. Available at: http:// www.consecol.org/vol6/iss1/art1. Accessed 31 January 2005.

Porter, M. E. 1991. America's green strategy. Scientific American 264(4):168.

Porter, M. E., and C. Van der Linde. 1995. Toward a new conception of the environment-competitiveness relationship. Journal of Economic Perspectives 9(4):97-118.

Putnam, R. D. 2000. Bowling alone: The collapse and revival of American community. New York, NY: Simon and Schuster. 541 p.

SCHNEIDER, A., AND H. IngRam. 1990. Behavioral assumptions of policy tools. Journal of Politics 52:510-529.

Selin, S., AND D. Chavez. 1995. Developing a collaborative model for environmental planning and management. Environmental Management 19:189195.

Sheley, R. L., and J. K. Petroff [eds.]. 1999. Biology and management of noxious rangeland weeds. Corvallis: Oregon State University Press. 438 p.

Shine, C., N. Williams, and F. Burhenne-Guilmin. 2005. Legal and institutional frameworks for invasive alien species. In: H. A. Mooney, R. N. Mack, J. A. McNeely, L. E. Neville, P. J. Shei, and J. K. Waage [EDS.]. Invasive alien species: A new synthesis. Washington, DC: Island Press. p 233-284.

Singleton, S. 1998. Constructing cooperation. Ann Arbor: University of Michigan Press. $165 \mathrm{p}$.

[SPSS] Statistical Package for the Social Sciences. 1999. SPSS Base 10.0 for Windows user's guide. Chicago, IL: SPSS, Inc. 548 p.
TANG, S. Y. 1994. Institutions and performance in irrigation systems. In: E. Ostrom, R. Gardner, and J. Walker [EDs.]. Rules, games and common pool resources. Ann Arbor, MI: University of Michigan Press. p 225-246.

Thill, D. C., J. M. Lish, R. H. Callihan, and E. J. Bechniski. 1991. Integrated weed management-a component of integrated pest management: A critical review. Weed Technology 5:648-656.

[USDA-FS] US Department of Agriculture-Forest Service. 1998. US Forest Service strategy for noxious and non-native invasive plant management: Stemming the invasive tide. Washington, DC: USDA-FS. 29 p.

[USDI-BLM] US Department of the Interior-Bureau of Land Management. 1996. Partners against weeds: Final action plan for the Bureau of Land Management. Washington, DC: BLM. 43 p.

VanBebBer R. 2001. CWMA cookbook: A recipe for success. Boise, ID: US Department of Agriculture, Forest Service, Intermountain Region.

WaGner, C. L. 2006. Building better bridges: Community-based collaboration and social capital in northwest Colorado [thesis]. Fort Collins, CO: Colorado State University. $186 \mathrm{p}$.

WEBER, E. P. 2003. Bringing society back in: Grassroots ecosystem management, accountability, and sustainable communities. Cambridge, MA: MIT Press. $317 \mathrm{p}$.

Woodall, C., A. Handler, and L. Broberg. 2000. Social dilemmas in grassland ecosystem restoration: integrating ecology and community on a Montana mountainside. Ecological Restoration 18:39-44.

WooLcock, M. 1998. Social capital and economic development: toward a theoretical synthesis and policy framework. Theory and Society 27:151-208.

Wondolleck, J. M., And S. L. YafFeE. 2000. Making collaboration work: Lessons from innovation in natural resources management. Washington, DC: Island Press. $277 \mathrm{p}$.

Yaffee, S. L., And J. M. Wondolleck. 1995. Building knowledge pools and relationsheds. Journal of Forestry 92(5):68. 